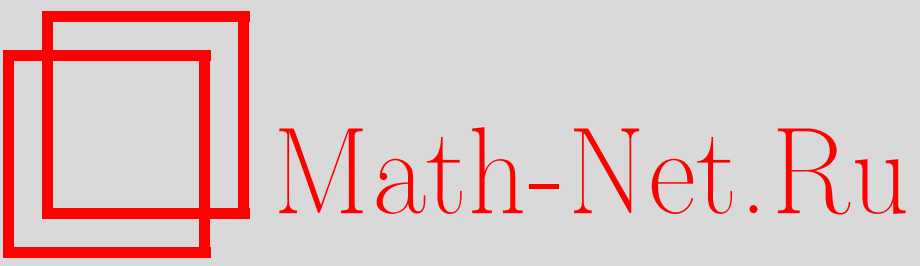

О. Б. Лупанов, В. В. Александров, А. Фрагела Коллар, Международная школа "Функциональный анализ, дифференциальные уравнения и их приложения", УМН, 1996, том 51, выпуск 1, 185-186

DOI: https://doi.org/10.4213/rm1577

Использование Общероссийского математического портала Math-Net.Ru подразумевает, что вы прочитали и согласны с пользовательским соглашением

http: //www.mathnet.ru/rus/agreement

Параметры загрузки:

IP : 3.85 .183 .62

26 апреля 2023 г., 13:06:37 


\section{МЕЖДУНАРОДНАЯ ШКОЛА “ФУНКЦИОНАЛЬНЫЙ АНАЛИЗ, ДИФФЕРЕНЦИАЛЬНЫЕ УРАВНЕНИЯ И ИХ ПРИЛОЖЕНИЯ”}

С 18 по 23 марта 1995 года в г. Пуэбла (Мексика) состоялась 1-я Международная Школа по функциональному анализу, дифференциальным уравнениям и их приложениям. Эта школа была организована Автономным Университетом г. Пуэбла (Beneverita Universidad Autonoma de Puebla - BUAP) совместно с Московским Государственным Университетом им. М. В. Ломоносова (МГУ). Президент Школы - академик РАН О. А. Олейник. Координаторы Школы - д.ф.-м.н., профессор физико-математического факультета BUAP А. Фрагела Коллар и д.ф.-м.н., профессор механико-математического факультета МГУ В. В. Александров. В организационный Комитет Школы вошли также крупные мексиканские математики.

Открытие Школы было приурочено к 45-ой годовщине создания физико-математического факультета BUAP. Проведение Школы было бы невозможно без той большой помощи, которую оказали Ректорат ВUАР и делегация ученых МГУ, специалистов в области дифференциальных уравнений, спектральной теории операторов, теории аппроксимаций, вычислительных методов, оптимизации и проблем механики.

В делегацию МГУ, возглавляемую деканом механико-математического факультета чл.-корр. РАН О.Б. Лупановым, входили профессора: акад. О. А. Олейник, В. В. Александров, В. А. Морозов, Б.Е. Победря, В.М. Тихомиров, А.А. Шкаликов. В работе Школы также принимали участие: испанские ученые - специалисты по прикладной математике Хосе М. Бальдасано (Директор Барселонского Метеорологического института) и профессор Мадридского Университета "Комплутенсе" Луис Г. Лавона; кубинские и российские специалисты, работающие в Мексике М. Хименес, Ф. Герра, В. Г. Болтянский, А. С. Поздняк, А. Давыдов, С. П. Левашкин.

Место проведения 1-й Международной Школы было выбрано не случайно. Три года назад по инициативе ученых и выпускников механико-математического факультета МГУ в Автономном Университете г. Пуэбла была создана Магистратура и Аспирантура по функциональному анализу, дифференциальным уравнениям, оптимизации и математическому моделированию. Поэтому ядро Школы составляли студенты и аспиранты, а также преподаватели мексиканских университетов. В рамках Школы работали 5 секций:

1. Дифференциальные уравнения.

2. Функциональньй анализ.

3. Оптимизация и оптимальное управление.

4. Численные методы и дискретная математика.

5. Математическое моделирование.

По каждой секции было сделано 1 или 2 пленарных доклада, а также от 10 до 20 секционных докладов. Перечислим названия только пленарных докладов.

О.А. Олейник. "Спектральные задачи теории усреднения дифференциальных операторов".

А. А. Шкаликов. "Матричные операторные модели и их применение в задачах математической физики". 
Луис Г. Лавона. "Полиномиальная непрерывность".

В.М. Тихомиров. "Математическая теория экстремалњнтх задач".

В.Г. Болтянский. "Метод шатров в теории экстремальных задач".

А.С. Поздняк. "Робастное управление линейными бесконечномерными системами".

В.М. Морозов. "Методы решения некорректно поставленных задач".

О.Б. Лупанов. "Об асимптотических оценках сложности схем".

А. Фрагела Коллар. "Некоторые оценки для спектра матричных операторов и их применение в задачах гидромеханики".

Б. Е. Победря. "Модели механики сплошной среды".

В. А. Садовничий, В.В.Александров, Т. Б. Александрова, Л. И. Воронин. "Математические модели для динамической имитации аэрокосмических полетов".

Федерико Ж. Сабина. "Рассеивание волн в материалах с микроструктурой".

Хосе М. Бальдасано. "Математическое моделирование атмосферных явлений".

Уже из перечня пленарных докладов видно, что проблемы, рассматриваемые на секциях, тесно связаны друг с другом. Поэтому слушатели посещали буквально все секции. Конечно, сейчас рано говорить о каких-то результатах по итогам работы данной Школы. Но один результат уже очевиден - это желание физико-математических факультетов других Университетов Мексики также начать деятельность по организации аспирантуры. Так, например, физико-математический факультет Автономного университета штата Нуэва Леон (г. Монтеррей) обратился с просьбой к механико-математическому факультету МГУ об оказании помощи в организации аспирантуры по математическому анализу, дифференциальным уравнениям и их приложениям.

Следует сказать несколько слов о культурной программе Школы. Мексиканские коллеги приложили максимум усилий, чтобы сделать ее интересной и насышенной. Это и посещение самой большой в мире пирамиды в окрестностях города Пуэбла (Чолула), экскурсия в столицу - город Мехико и знаменитые пирамиды Солнца и Луны, концерты народных ансамблей. Делегация Московского Университета была принята губернатором штата Пуэбла. Во время этой встречи учеными были вручены дипломы почетных гостей города Пуэбла. В течение всей Школы стояла прекрасная погода, и даже грозный вулкан Попокатепетль на окраине Пуэблы перестал извергать пепел.

О. Б. Лупанов, В.В. Александров, А. фрагела Коллар 